\title{
AFFORDABILITY AS AN OBSTACLE IN THE HOUSING DEVELOPMENT PROCESS IN EGYPT FOR LOW-INCOMES: CASE OF BASHAYER AL-KHAIR
}

\author{
SHERINE SHAFIK, FAHD HEMEIDA \& AMR SHARABY \\ Arab Academy for Science, Technology \& Maritime Transport, Alexandria, Egypt
}

\begin{abstract}
Worldwide, governments set their strategies, policies, and regulations to develop affordable houses based on their local low/middle-income categories' demands. However, affordable housing is directly affecting the housing development process. Some countries do not put this into consideration. This paper has a main aim which is the creation of a checklist to evaluate the affordability of the housing projects so as to evaluate a recent affordable housing project with a comparison between old projects in Egypt. In a national view, Egypt, the supplied unit increased to 500,000 units with only 188,697 occupied units. This represents $37.7 \%$ of the supplied units. According to "CAPMAS 2017", there are 13 million housing units which are not used in Egypt. Therefore, the researcher had to choose qualitative, quantitative, analytical and field methodology to prove the aim of the paper. However, during the recent years the government of Egypt created a housing project named Bashayer Al-Khair, as a first step of the future strategy to create more projects of Bashayer Al-Khair 2, 3. This project was selected to be the case study of the paper in order to evaluate its affordability because it is the first step of many more affordable housing projects to come. Thus, a questionnaire was conducted on 50 local households. Accordingly, the results proved that $77 \%$ of the local households are not satisfied with the housing while $22 \%$ find that the housing units are not financially affordable. Hence, that results show a high percentage of failure in affordability.

Keywords: affordable housing, housing development, low-income, affordability.
\end{abstract}

\section{INTRODUCTION}

In a normal parlance, "affordable" is a word with flexible meanings. Most people, translate it into a simple question: "Do I have the money to pay for it?" The word "affordable", also carries the connotation of income and is fundamentally linked to it. Affordable housing can be defined as, "A relationship between housing and people. For some people, all housing is affordable, no matter how expensive it is; for others, no housing is affordable unless it is free" [1].

Usually, affordable housing is one of the essential structures of any housing development strategy. However, affordability on the housing sector turned into an obstacle of the housing development process in Egypt in the last decade.

Unlike any housing development strategies, The Egyptian strategy faces a puzzling phenomenon of large-scale vacancies of housing units in inner cities, in addition to the shortage of housing supply and the rising of demand [1].

The average number of housing units that could cover the shortage of housing in Egypt is approximately 2.5 million units. Although there are around 7.8 Million units that are not used, these units are either out of reach for the middle or low-income households due to their high prices. Another reason could be that the units are not efficient because of the shortage in both the infrastructure and facilities.

These unused units are either closed, which represents the housing units that are sold or rented but they are unoccupied [1]. 


\section{CHARACTERIZATION AND AFFORDABILITY OF LOW-INCOME HOUSING}

\subsection{Classification of low-income}

The definition of the low-income category in Egypt is the targeted category of the population for the research. They are manifested in the population that has no proportion between their incomes and their basic needs of life. This category has no possibility of having an affordable housing in the current housing market [1].

2010 states that poverty is affecting around $21.6 \%$ of the total population of Egypt. This means that around 13.7 million persons in Egypt are facing problems to achieve their basic human needs of living including housing and health care. $22 \%$ of the total population of Egypt's income is not higher than $2 \$(36$ LE) per day, and according to a survey, 2011, the average income of the low-income population is 700 LE per month [1].

\subsection{Distribution of low-income according to cities}

The government of Egypt categorizes them into a two type, low-income, and extremely lowincome population to clarify the need of each category [2].

It is necessary to classify their salary into fixed income which is annually or monthly and their total income, which is their salary plus any extra source of money (Income $=$ Salary + Extras). This is to clarify the scale of their problem [3].

Table 1 shows the percentage of the low-income and extremely low-income population to the total population. Additionally, the average annual personal income, and the percentage of the salary of low-income according to the total salary and the percentage of their salary to their income, annually [3].

\subsection{Affordability of low-income housing}

\subsubsection{Supply and demand of affordable housing}

As a solution of housing problems in Egypt, between 2012 and 2018, the Egyptian Government established a plan to create 1 million affordable housing units [4].

The supplied unit increased to 500,000 units. Only 188,697 units are occupied (Fig. 1), which is $37.7 \%$ of the supplied units [6].

Typically, affordable housing projects should be created for low-income considering their needs. Therefore, the supplied units to low-income have reached only $7 \%$ of their demand yearly. On the other hand, the supplied units in 16 cities reached only $5 \%$ of low-income demand [4].

In a focused view (Fig. 2), 163,000 low-income families are forming yearly, however affordable housing projects are reaching only $16 \%$ of these families. These housing projects reached a maximum percentage of $75 \%$ in Cairo, El-Suez, and El-Sharqea. While in South Egypt, which contains a high percentage of low/middle categories, it reached $10 \%$ or lower [4].

For the last seven years, the Egyptian Government promised to spend 136.5 billion Egyptian Pounds on affordable housing projects. However, the actual spent amount is lower than that strategy by $57 \%$.

With the increasing of the disregard to the development strategy, there are subsequences such as low quality, more red tape, transferring money to different projects and no demand on units [4]. 
Table 1: Distribution of low-income population in Egypt. (Source: World Bank, in Egypt, 2010.) Edited by the researcher.

\begin{tabular}{|c|c|c|c|c|c|}
\hline \multirow[b]{2}{*}{$\begin{array}{l}\text { City } \\
\text { ( } 27 \text { Egyptian } \\
\text { cities) }\end{array}$} & \multirow{2}{*}{$\begin{array}{l}\text { Annual average } \\
\text { income according } \\
\text { to the local } \\
\text { production (L.E.) }\end{array}$} & \multicolumn{2}{|c|}{ Low-income population } & \multicolumn{2}{|c|}{$\begin{array}{l}\text { Percentage of } \\
\text { low-income } \\
\text { population salary }\end{array}$} \\
\hline & & $\begin{array}{l}\text { Total low- } \\
\text { income } \\
\text { population } \\
(\%)\end{array}$ & $\begin{array}{c}\text { Extremely } \\
\text { low- } \\
\text { income } \\
\text { population } \\
(\%)\end{array}$ & $\begin{array}{c}\text { To the } \\
\text { total } \\
\text { local } \\
\text { salaries } \\
(\%)\end{array}$ & $\begin{array}{l}\text { To their } \\
\text { income } \\
(\%)\end{array}$ \\
\hline Cairo & 7726.4 & 7.6 & 1.7 & 4.9 & 43.2 \\
\hline Alexandria & 8978.3 & 6.4 & 1.2 & 4.5 & 44.4 \\
\hline Port Said & 10549.7 & 4.4 & 1.7 & 2.4 & 37 \\
\hline Suez & 8745.8 & 1.9 & 0.3 & 1.5 & 43.8 \\
\hline Damietta & 7883.5 & 1.1 & 0.2 & 1.2 & 31.8 \\
\hline Daqahlia & 9111.5 & 9.3 & 1 & 6.4 & 40.1 \\
\hline Sharqia & 8700.4 & 19.2 & 1.9 & 13 & 37.3 \\
\hline Qalubia & 8134.4 & 11.3 & 1.8 & 9.3 & 52.6 \\
\hline Kafr al-Sheikh & 8927.9 & 11.2 & 2.1 & 6.9 & 39.7 \\
\hline Gharbia & 8799.6 & 7.6 & 0.8 & 6.9 & 52.7 \\
\hline Munufia & 9854.0 & 17.9 & 3.1 & 14.2 & 39 \\
\hline Beheira & 9451.6 & 23.5 & 3.8 & 17.8 & 39 \\
\hline Ismailia & 8970.2 & 18.8 & 4.3 & 13.7 & 40.2 \\
\hline Giza & 8242.8 & 23 & 7.6 & 16.5 & 43.2 \\
\hline Beni Sweif & 8857.4 & 41.5 & 11.5 & 33.1 & 44.8 \\
\hline Fayoum & 8433.7 & 28 & 5.9 & 19.8 & 36 \\
\hline Minya & 8655.9 & 30.9 & 7 & 23.7 & 39.4 \\
\hline Assiut & 8019.6 & 61 & 31.4 & 48.3 & 40.4 \\
\hline Sohag & 7329.7 & 47.5 & 18.5 & 36.3 & 41.2 \\
\hline Qena & 6387.5 & 39 & 11.5 & 28.5 & 40.2 \\
\hline Luxer & 9105.6 & 40.9 & 14.3 & 30.8 & 42.3 \\
\hline Aswan & 7057.4 & 18.4 & 0.4 & 13.9 & 40.3 \\
\hline Red Sea & 8460.7 & - & - & - & - \\
\hline Wadi al-Gadid & 12682.2 & - & - & - & - \\
\hline Matruh & 10346.1 & - & - & - & - \\
\hline North Sinai & 8884.0 & - & - & - & - \\
\hline South Sinai & 12454.6 & - & - & - & - \\
\hline Egypt & 10246.1 & 21.6 & 6.1 & 15.2 & 41.3 \\
\hline
\end{tabular}






Figure 1: The relation between supplied units, occupied units and government plan duration from 2011 to 2018. (Source: CAPMAS, 2018 [6] and "Ministry of Urban Planning, 2017/2018”.) Edited by the researcher.

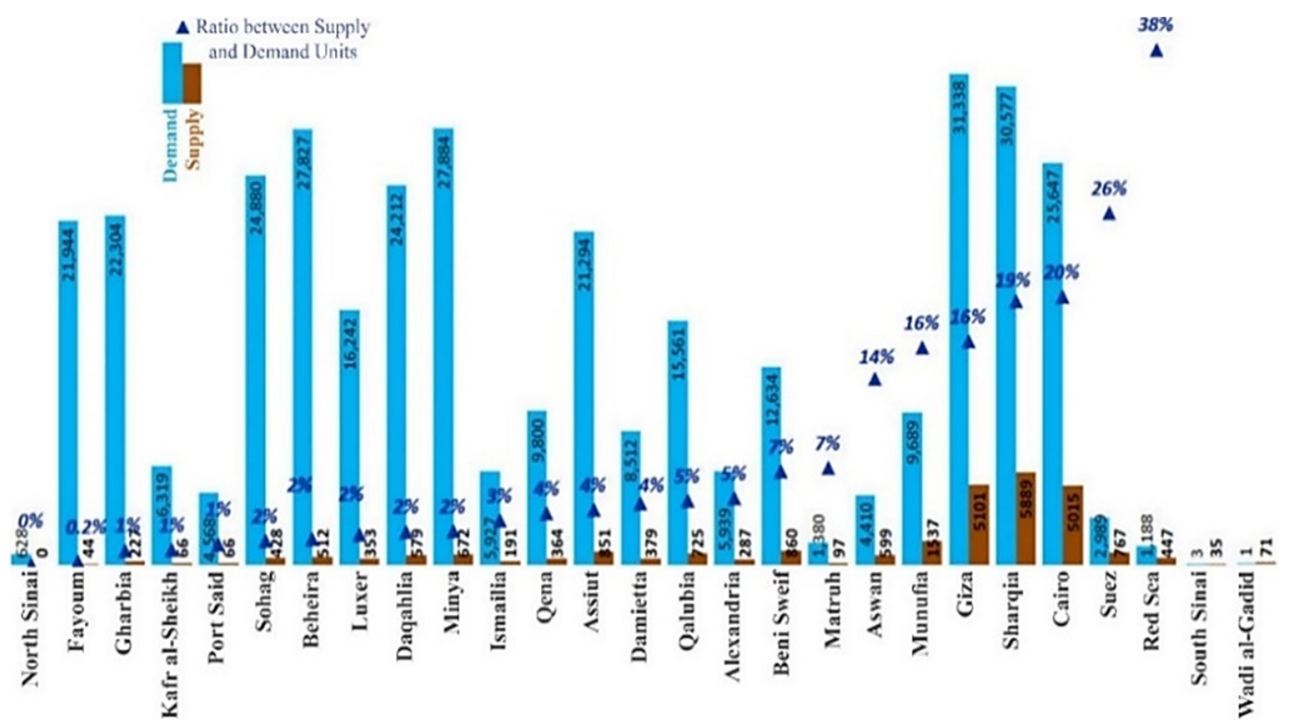

Figure 2: Relation between supply and demand units according to cities. (Source: CAPMAS, 2017 [6].) Edited by the researcher.

\subsubsection{Occupancy ratio of affordable housing}

In a detailed view (Fig. 3) of the supply and demand in Egypt, the affordable housing projects have been distributed all over Egypt in 27 cities. The occupancy level of the affordable houses is lower than $80 \%$ of the units in 20 cities, and lower than $50 \%$ in 17 cities and 0 occupied units in North Sinai [4]. 




Figure 3: Occupancy ratio according to cities. (Source: CAPMAS, 2017 [6].) Edited by the researcher.

\section{METHODOLOGY}

It is fundamental to the study to give a general description of the procedure, methods, and variables selected to support and manage qualitative and quantitative information to the study of Bashayer Al-Khair.

\section{CASE OF BASHYER AL-KHAIR}

In this study, the case of Bashayer Al-Khair, which is a developed area of "Ghait Al-Enab", is recently one of the leading distinguished national cases, represented by the Egyptian Armed forces and Alexandria Council. They cooperated with the society to implement the strategy not only to develop Ghait Al-Enab to Bashyer Al-Khair, but to also replace it with an efficient affordable housing for low-income [5]. A questionnaire methodology done with 50 families in the area was held for specification of the affordability value.

4.1 Results and evaluations of data coming from the study case

\subsubsection{Household results}


Figure 4: Household jobs analysis case of Bashyer Al-Khair. (Source: The researcher.) 




Figure 5: Household analysis case of Bashyer Al-Khair. (Source: The researcher.)

\subsubsection{Architectural results}


Figure 6: Architectural analysis case of Bashyer Al-Khair. (Source: The researcher.) 


\subsubsection{Housing results}
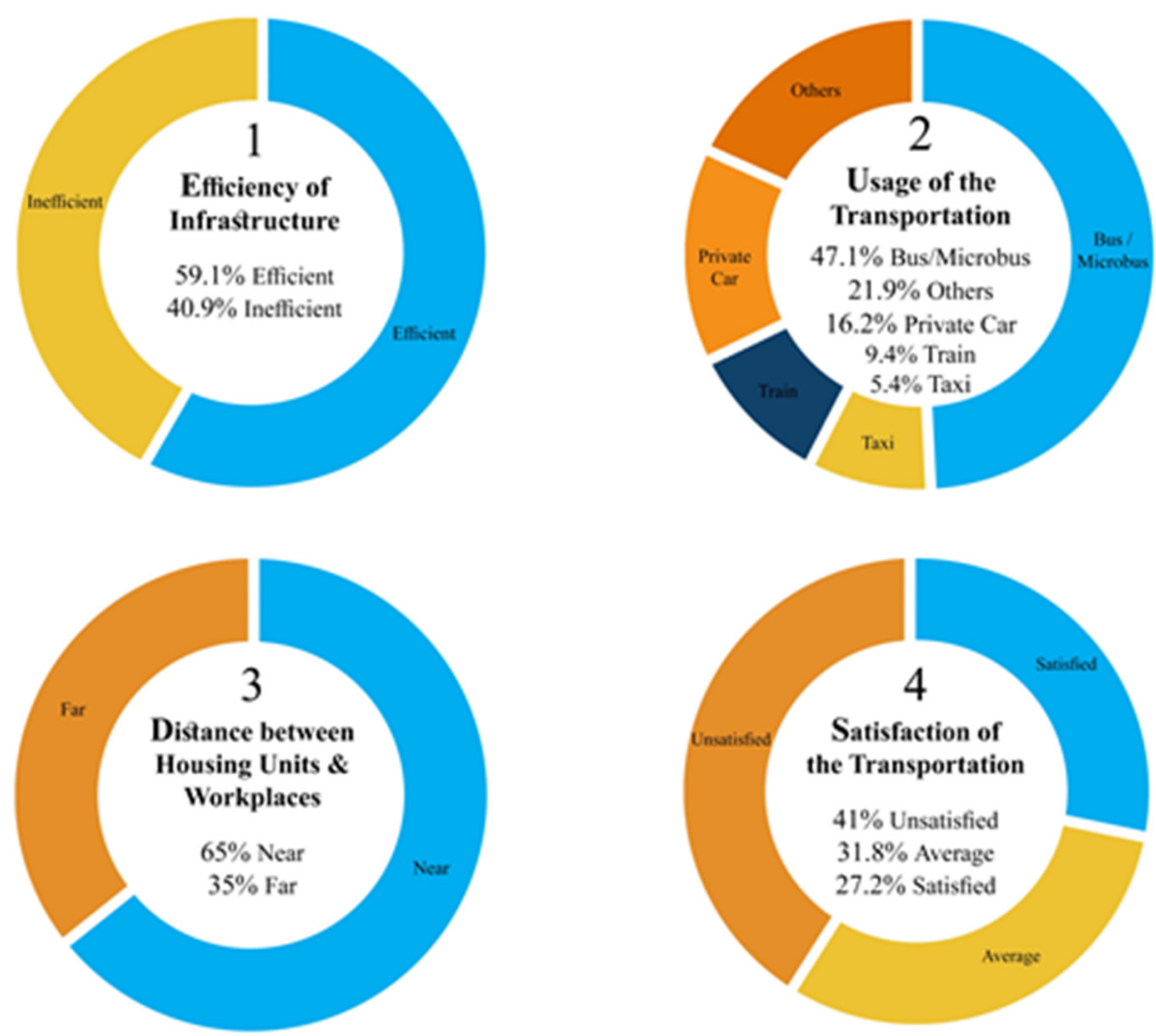

Figure 7: Housing analysis case of Bashyer Al-Khair. (Source: The researcher.)

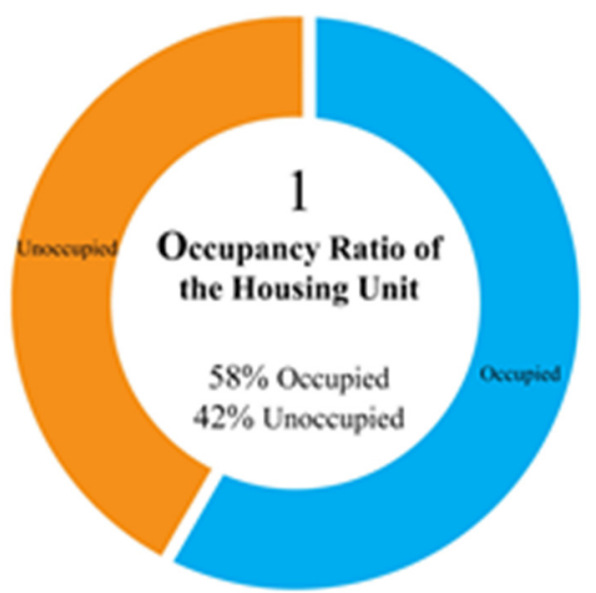

Figure 8: Occupancy ratio of housing units case of Bashyer Al-Khair. (Source: The researcher.) 


\subsubsection{Financial results}



Figure 9: Financial analysis case of Bashyer Al-Khair. (Source: The researcher.)

\subsection{Evaluation of the case}

Through the previous analysis using filed, qualitative and quantitative methodologies, the ability to evaluate the affordability is achieved. 50 different families of the case were chosen as the sample of the study with an average of one family (represents one housing unit) per residential building. By asking the householder of those families, an interview was made with them by the researcher. The next evaluation is divided into 4 main approaches: household, architectural, housing and financial approach. Each one has its own factors and its own evaluation value. Considering that each approach has a differently direct or indirect effect on the housing affordability.

\subsubsection{Household evaluation}

It affects $10 \%$ of the affordable housing project evaluation into the factors shown in Table 2.

Table 2: Evaluation of the household approach of the project. (Source: The researcher.)

\begin{tabular}{|c|c|c|}
\hline Factors & $\begin{array}{c}\text { Evaluation value } \\
(\%)\end{array}$ & $\begin{array}{c}\text { Total value } \\
(\%)\end{array}$ \\
\hline $\begin{array}{l}\text { The ratio between the vacant units to the } \\
\text { total supplied units. }\end{array}$ & 1 & \multirow{5}{*}{4 out of 10} \\
\hline $\begin{array}{l}\text { The ratio between the rented units to the } \\
\text { total supplied units. }\end{array}$ & 0.5 & \\
\hline The limited spread of sub-rent system. & 0 & \\
\hline $\begin{array}{l}\text { The provision of social facilities and youth } \\
\text { employment. }\end{array}$ & 1.5 & \\
\hline $\begin{array}{l}\text { Improving concept of new small projects } \\
\text { and providing new jobs for the households. }\end{array}$ & 1 & \\
\hline
\end{tabular}




\subsubsection{Architectural evaluation}

It affects $25 \%$ of the affordable housing project evaluation into the factors shown in Table 3.

Table 3: Evaluation of the architectural approach of the project. (Source: The researcher.)

\begin{tabular}{|c|c|c|}
\hline Factors & $\begin{array}{c}\text { Evaluation value } \\
\qquad(\%)\end{array}$ & $\begin{array}{l}\text { Total value } \\
\qquad(\%)\end{array}$ \\
\hline $\begin{array}{l}\text { Enough spaces between the buildings in the } \\
\text { affordable housing project. }\end{array}$ & 2 & \multirow{5}{*}{14 out of 25} \\
\hline $\begin{array}{l}\text { The efficiency of the use of horizontal and } \\
\text { vertical areas. }\end{array}$ & 4 & \\
\hline $\begin{array}{l}\text { Housing units fit the basic needs of any } \\
\text { households. }\end{array}$ & 4 & \\
\hline $\begin{array}{l}\text { Flexible inner design of the affordable } \\
\text { housing units. }\end{array}$ & 2 & \\
\hline The efficiency of the used structure system. & 2 & \\
\hline
\end{tabular}

\subsubsection{Housing approach}

It affects $45 \%$ of the affordable housing project evaluation into the factors shown in Table 4 .

Table 4: Evaluation of the housing approach of the project. (Source: The researcher.)

\begin{tabular}{|c|c|c|}
\hline Factors & $\begin{array}{c}\text { Evaluation value } \\
(\%)\end{array}$ & $\begin{array}{l}\text { Total value } \\
\qquad(\%)\end{array}$ \\
\hline The efficiency of the engineering team. & 2 & \multirow{9}{*}{32 out of 45} \\
\hline $\begin{array}{l}\text { The efficiency of the infrastructure of the } \\
\text { affordable housing project. }\end{array}$ & 4 & \\
\hline Access to public transportation. & 2 & \\
\hline $\begin{array}{l}\text { The distances between the main facilities: } \\
\text { (e.g. schools and hospitals). }\end{array}$ & 5 & \\
\hline $\begin{array}{l}\text { The efficiency between the urban } \\
\text { environment of the project and the social } \\
\text { and cultural background. }\end{array}$ & 5 & \\
\hline $\begin{array}{l}\text { The population of the housing project with } \\
\text { no effect on the balance between } \\
\text { environment and housing approaches. }\end{array}$ & 4 & \\
\hline $\begin{array}{l}\text { Sustainable construction material from the } \\
\text { surrounding environment. }\end{array}$ & 1 & \\
\hline $\begin{array}{l}\text { The location of the affordable housing } \\
\text { project from the workplaces. }\end{array}$ & 4 & \\
\hline Access to recreational public spaces. & 5 & \\
\hline
\end{tabular}


4.2.4 Financial approach

It affects $20 \%$ of the affordable housing project evaluation into the factors shown in Table 5 .

Table 5: Evaluation of the financial approach of the project. (Source: The researcher.)

\begin{tabular}{|c|c|c|}
\hline Factors & $\begin{array}{c}\text { Evaluation value } \\
(\%)\end{array}$ & $\begin{array}{l}\text { Total value } \\
(\%)\end{array}$ \\
\hline $\begin{array}{l}\text { The cost of meter square of the affordable } \\
\text { housing unit. }\end{array}$ & 3.5 & \multirow{4}{*}{14 out of 20} \\
\hline The availability of rental affordable approach. & 4 & \\
\hline The direct expenses of the household. & 3.5 & \\
\hline The indirect expenses of the household. & 3 & \\
\hline
\end{tabular}

4.3 Advantages and disadvantages of the case

\subsubsection{Advantages}

A. Financial Approach

1. Acceptable cost of unit for local residents (Ghait El-Anab residents).

2. The availability of rental concept.

B. Household Approach

1. Provided social facilities.

C. Architectural Approach

1. High efficiency of the use of horizontal and vertical areas.

2. Housing units fit the needs of the households.

D. Housing Approach

1. Effective infrastructure of the case.

2. Low distance between the main facilities and housing units.

3. Close to workplaces and high access to recreational spaces.

E. General Advantages

1. New affordable housing units for low/middle-income categories.

2. New facilities such as hospitals, sports club, and workplaces.

\subsubsection{Disadvantages}

A. Financial approach

1. Extremely high cost of the housing units for the new residents.

2. Rental units use profitable material in the case for the middle/high category.

3. Direct or indirect expenses are not acceptable for the new residents.

B. Household approach

1. More than quarter of the units are vacant.

2. Wide-spread of sub-rent system. 
C. Architectural approach

1. The Egyptian Building Regulations, building height should be $1.5 x$ of the street width. In this case, the building's height is $2.1 x$ the street width and in some locations $3 x$ the street width.

2. Some cracks were found in the structure system.

3. Low flexibility of inner designs, and overcrowded units per buildings.

D. Housing approach

1. Low-efficiency of the engineering team.

2. Because of low access of public transportation, residents had to choose illegal transportation, e.g. Toktok.

3. Unsustainable building materials.

E. General disadvantages

1. The most influential drawback is that the GOE had to deal with stockholders to construct the housing project. Thus, the housing units were divided upon them, so as to be profitable using low-income category.

2. High crime ratio in the case.

3. According to CAPMAS 2017, 13 million vacant units in Egypt. These projects added more vacant units [6].

\section{CONCLUSION}

"Housing Matters", the government considered the housing approach to be very effective in any affordable housing project, and did not put the household approach in considerations (Fig. 10). On the other hand, the financial approach was also one of the points that were taken into account in Bashyer Al-Khair, but the average architectural approach evaluation decreased affordability.

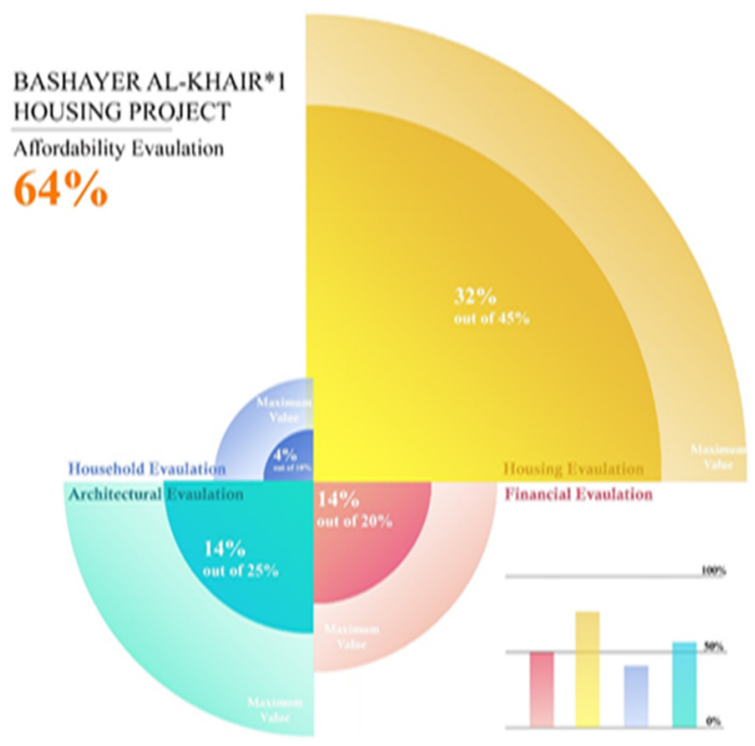

Figure 10: Affordability evaluation of the project. (Source: The researcher.) 
The housing approach in Bashyer Al-Khair marked the highest achievement of the project reaching $71.1 \%$. However, the household approach was the lowest evaluation marking $40 \%$, which is below the basic standards of any successful affordable housing project. Nevertheless, the financial approach achieved high evaluation reaching $70 \%$, while the architectural evaluation was of an average achievement which is $56 \%$.

On the other hand, the case of relocation for the local residents was successful. The government had to set a consideration of being close to workplaces, and the availability of transport in the new area [5].

\section{REFERENCES}

[1] Ibrahim, M.R., How do people select their residential locations in Egypt? The case of Alexandria. Cities, 62, pp. 96-106, 2017.

[2] Sims, D., Kamal, H. \& Solomon, D., Housing Study for Urban Egypt, U.S. Agency for International Development: Egypt, 2008.

[3] Fahmi, W. \& Sutton, K., Greater Cairo's housing crisis: Contested spaces from inner city areas to new communities. Cities, 25, pp. 277-297, n.d.

[4] Askar, E.O., Valuable engineering as one of the solutions to the problem of low-income housing. PhD thesis, The Egyptain National Center for Housing and Construction Research, Architectural Engineering, University of Cairo: Cairo, 2011.

www.cpas-egypt.com/pdf/ImanOmarAskar/Ph.D/Ph.D.pdf. Acessed on: 18 May, 2020.

[5] Abd El-Monem, N., Steps of sustainable management of deteriorated area through public sector and population partnership. 1st International Conference on Towards a Better Quality of Life, 24 Nov. 2017. https://ssrn.com/abstract=3163003 and http://dx.doi.org/10.2139/ssrn.3163003.

[6] Central Agency for Public Mobilization and Statistics website 2019. www.capmas.gov.eg/. 